\title{
ЭКОЛОГИЧЕСКИЕ ПРОБЛЕМЫ ЗЕМЕЛЬ СЕЛЬСКОХОЗЯЙСТВЕННОГО НАЗНАЧЕНИЯ
}

\section{Карина Куандыковна Сайдалина}

Сибирский государственный университет геосистем и технологий, 630108, Россия, г. Новосибирск, ул. Плахотного, 10, обучающийся, тел. (905)959-57-14, e-mail: saidalina.karina@mail.ru

\section{Надежда Ивановна Добротворская}

Сибирский государственный университет геосистем и технологий, 630108, Россия, г. Новосибирск, ул. Плахотного, 10, доктор сельскохозяйственных наук, профессор кафедры кадастра и территориального планирования, тел. (383)344-31-73, e-mail: dobrotvorskaya@mail.ru

В статье рассмотрены экологические проблемы земель сельскохозяйственного назначения. Описаны основные причины их возникновения. Показаны последствия причинения вреда почве. Сделан вывод о необходимости освоения адаптивно-ландшафтной системы земледелия.

Ключевые слова: земли сельскохозяйственного назначения, плодородие почв, агрохимия, эрозия, животноводство, малые реки, адаптивно-ландшафтные системы

\section{ECOLOGICAL PROBLEMS OF AGRICULTURAL LAND}

\section{Karina K. Saidalina}

Siberian State University of Geosystems and Technologies, 10, Plakhotnogo St., Novosibirsk, 630108, Russia, Student, phone: (905)959-57-14, e-mail: saidalina.karina@mail.ru

\section{Nadezhda I. Dobrotvorskaya}

Siberian State University of Geosystems and Technologies, 10, Plakhotnogo St., Novosibirsk, 630108, Russia, Ph. D., Professor, Department of Cadastre and Territorial Planning, phone: (383)344-31-73, e-mail: dobrotvorskaya@mail.ru

The article deals with the environmental problems of agricultural lands. The main reasons for their occurrence are described. The consequences of causing harm to the soil are shown. The conclusion is made about the need to master the adaptive landscape farming system.

Keywords: agricultural land, soil fertility, agrochemistry, erosion, animal husbandry, small rivers, adaptive landscape systems

Сельское хозяйство является одним из важнейших источников обеспечения населения продовольствием, отвечающим за его благосостояние. Площадь земель сельскохозяйственного назначения составляет 383,7 млн га, что составляет 22,4\% земельного фонда Российской Федерации. Но, к сожалению, на данный момент сельское хозяйство оказывает негативное влияние на окружающую среду наряду с промышленностью.

Все процессы, которые связаны с сельским хозяйством и производством, подвергают изменениям окружающую среду. В дальнейшем это может привести к нарастанию экологических проблем. 
Цель исследования: изучить экологические проблемы, связанные с землями сельскохозяйственного назначения.

Задачи: рассмотреть основные проблемы и причины их возникновения.

Сельскохозяйственное производство оказывает влияние на почвенные свойства, процессы, режимы, почвообразовательные процессы и генезис почв. Одними из важнейших свойств почвы, с точки зрения экологии являются: трансформация минеральных веществ, поступающих в почву, их закрепление и накопление. Минеральные удобрения ежегодно вносятся на поля для восполнения вымываемых химических элементов из почвы. Они также регулируют процессы обмена веществ в растениях. Но часто правила использования удобрений не соблюдаются. Внесение удобрений в высоких дозах, плохое хранение, неправильная транспортировка приводят к загрязнению окружающей среды и оказывают влияние на здоровье человека. Также используя современные науки такие, как: мелиорация, почвоведение, агрохимия и др. - люди намеренно воздействуют на процессы, протекающие в почве, которые в дальнейшем должны помочь в повышении ее продуктивности и улучшении. Но современные технологии достигли своего предела в экологическом, энергетическом и продукционном аспектах, и дальнейшее их влияние приведёт к резкому ухудшению окружающей среды [1].

Ухудшение экологической ситуации при ведении сельского хозяйства также часто обусловлено неправильной распашкой территорий, неграмотным осушением и орошением, влиянием механических обработок территорий. При осуществлении основных производственных процессов в сельском хозяйстве таких, как вспашка, посев, обработка, уборка продукции возникает ряд неблагоприятных последствий.

При использовании мобильных энергетических средств (тракторов, автомобилей) происходит химическое и механическое загрязнение атмосферы, загрязнение среды жидкими нефтепродуктами, разрушение и уплотнение почвы в результате давления на почву. Сельское хозяйство потребляет почти $40 \%$ нефтепродуктов от их общего потребления. Отработанные газы при сжигании топлива представляют значительную экологическую опасность.

При обработке почвы развивается водная, ветровая и техническая эрозии. Без своевременных мер по предупреждению эрозии развитию экономики страны наносится огромный ущерб. Снижается плодородие почв, ухудшаются ее свойства и биологическая активность [2].

Развивающееся на промышленной основе животноводство также становится мощным фактором загрязнения окружающей среды. Животноводство является причиной возникновения парниковых газов. По данным исследований, доля производства парниковых газов животными составляет 18\%. Углекислый газ, вырабатываемый коровами, составляет 9\% от общих выбросов в атмосферу, метан - 37\%, аммиак - 70\%. Метан оказывает влияние на 
повышение температуры Земли.Также животноводство требует большого потребления воды. Примером является то, что на производство 1 кг мяса расходуется 4300 литров воды. Эти расчёты включают в себя расходы воды, необходимые для полива пастбищ, организации водопоя и мытья животных. Общие расходы водных ресурсов на животноводство по всему миру составляют от 20 до $70 \%$ [3].

Пастбища, фермы и прочие угодья занимают обширную часть территорий, что имеет свои последствия. Присутствие большого количества животных не очень хорошо сказывается на состоянии почвы, происходит деградация земель из-за уплотнения почвы и ее эрозии. Очень часто почва загрязняется химикатами, которые используются в хозяйстве для ухода за животными. Расширение пастбищ и полей, которые необходимы для выращивания различных культур, очень часто ведет за собой вырубку ближайших лесных массивов.

В последнее время актуальность приобретают вопросы, связанные с сохранением от истощения и загрязнения малых рек. К малым рекам относят реки длиной до 100 км. Малые реки играют огромную роль в сельском хозяйстве и промышленности. Они являются основными источниками водоснабжения и входят в состав системы ландшафтов. Несмотря на большое значение малых рек, их загрязнение и усыхание вызывает большую тревогу, так как мер по их сохранению принимается недостаточно. К основным причинам обмеления рек относятся: распашка склонов и пойм рек, что приводит к смыву почв и заилению пойм рек, забор воды на орошение, промышленные и другие нужды и тд. Загрязнение вод малых рек происходит по причине нахождения на их берегах мелких предприятий лесной, пищевой и сельскохозяйственной промышленности с отсталой технологией очистки воды.

При решении всех этих проблем на первый план должны выходить следующие задачи: сохранение и восстановление биоразнообразия, размещение сельскохозяйственных угодий в соответствии с агроэкологическими условиями, согласование животноводства и земледелия, создание инфраструктуры агроландшафтов, сокращение механического воздействия на почву. Все эти задачи решаются путём освоения адаптивно-ландшафтных систем земледелия [4].

Исходя из всего вышеизложенного, можно сделать вывод, что состояние земель сельскохозяйственного назначения является далеко не благоприятным. Сельское хозяйство оказывает огромное влияние на состояние почвы и экологии в целом. На данный момент охрана окружающей среды контролируется Федеральным законом «Об охране окружающей среды» от 10.01.2002 №7-Ф3. Он регулирует отношения в сфере взаимодействия общества и природы, возникающие при осуществлении деятельности, связанной с воздействием на природную среду как важнейшую составляющую окружающей среды, являющуюся основной жизни на Земле, в пределах территории Российской Федерации [5]. 


\section{БИБЛИОГРАФИЧЕСКИЙ СПИСОК}

1. ЭКОЛОГИЧЕСКИЕ ПРОБЛЕМЫ ЗЕМЛЕДЕЛИЯ [Электронный ресурс] - Режим доступа: https://cyberleninka.ru/article/n/ekologicheskie-problemy-zemledeliya/viewer.

2. Экологические проблемы сельскохозяйственного использования земли [Электронный pecypc] - Режим доступа: https://www.agroxxi.ru/amp/zhurnal-agromir-xxi/statirastenievodstvo/yekologicheskie-problemy-selskohozjaistvennogo-ispolzovanija-zemli.html.

3. Biomass use, production, feed efficiencies, and greenhouse gas emissions from global livestock systems / Mario Herrero, Petr Havlík, Hugo Valin, An Notenbaert, Mariana C. Rufino // Edited by William C. Clark, Harvard University, Cambridge, MA.

4. Кирюшин В.И. Методическое руководство "Агроэкологическая оценка земель, проектирование адаптивно-ландшафтных систем земледелия и агротехнологий" Под редакцией академика РАСХН В.И. Кирюшина и академика РАСХН А.Л. Иванова / Кирюшин В.И. - М.: Росинформагротех, 2015. - $794 \mathrm{c}$.

5. Федеральный закон от 20.12.2001 N 7-ФЗ «Об охране окружающей среды» [Электронный ресурс] - Режим доступа: http: //docs.cntd.ru/document/901808297.

(C) К. К. Сайдалина, Н. И. Добротворская, 2021 